Cozens, Bonnington, Francis Wheatley, and many others who, although not so widely known, were none the less masters of their craft.

Some of the pictures have an adventitious interest in addition to their artistic merits. For example, the Sandby gouache described in the catalogue as "Castle with Figures and Horses in the Foreground" is one of a number painted at Windsor, and another version is in the Royal Library there; it represents the Winchester Tower and the Hundred Steps. Incidentally, Sandby used powder colours mixed with isinglass and hastened the drying of his pig. ments by thinning them with gin, a practice not unknown to later generations.

In much the same sort of way, three of the Gainsborough drawings are interesting because they have been varnished. This was then the common practice when sketches in chalk or charcoal were intended to be used for teaching purposes. It destroyed so much of the texture and charm of the medium that such pictures are rarely seen in public exhibitions.

An artistic point to notice is the astonishing modernity of treatment displayed by many of the paintings. This is particularly well seen in "A View of Cayne Waterfall, near Dolgelly, North Wales” by Girtin. The rendering of the water reminds one so strongly of "A Waterfall" by J.D. Innes that one is tempted to speculate whether the latter could have seen the old master's work at some time. Finally, if anyone should imagine that a full palette is necessary for water-colour painting, let him, or her, ponder long and carefully over two or three of the Turners executed solely with blue, yellow ochre and Venetian red, and, perhaps, a touch of Chinese white. Not all the colours of the rainbow could convey the artist's message more clearly or more vividly.

A. T. HopwOoD

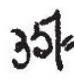

\section{CONFERENCE ON FOUNDRY}

\section{STEEL MELTING}

$\mathrm{O}^{\mathrm{N}}$ September 22 and of, the Steel Castings Division of the Vrotish Iron and Steel Research Association held, a Ashorne Hill, near Leamington Spa, a conferenbo devoted to a consideration of recent scientific datrelopments in melting steel in a manner and of a q ality suitable for making into steel castings.

In farly historical times, metals were used in the form or shape in which they happen to have been cast ; later, metals were cast to the shape desired, so that the founder of metals is bound to look upon the operation of melting metals as subsidiary to the more intricate operation of casting to the desired shape. Although to-day the bulk of steel is made in furnaces of large capacity, and is cast in cast-iron moulds to form ingots of relatively simple geometric shapes which are afterwards mechanically worked into the shape or section required, there remains a very important section of metallurgical industry, the foundry industry, in which the demand for molten metal is determined by the founder and the rate of his supply of suitable moulds in which the metal can be cast. In a few large steel-works in Great Britain, steel is melted and is cast either into ingots or castings in accordance with the needs for either; but this is the exception rather than the rule, and in the majority of steel foundries the demand is for smaller quantities of steel at frequent intervals at a somewhat higher temperature than is required for ingot production.
Thus the general problem of supplying liquid steel for a foundry differs in certain distinct ways from that of supplying bulk steel for ingot manufacture, and it was the object of this conference to discuss these differences with the view of guiding steel founders in the choice of the several types of steelmelting furnaces available to them. In actual fact the conference went much further than this, for not only did it provide a scientific exposition of the essential characteristics of present-day furnaces, but also, having dealt with certain developments being sponsored by the British Iron and Steel Research Association, it went on to indicate likely trends in the future.

The conference was arranged in four sessions held during the two days. The chairman for the first day was Mr. Richard Lamb, well known and highly esteemed in the industry, and chairman also of the Melting Sub-Committee under the guidance of which the conference had been arranged. Mr. Lamb was unable to be present on the second day, so that the chair was then taken over by Mr. H. Everard, a member of the same Sub-Committee and one who has been most active in the promotion of research in the important steel foundry with which he is connected. Fourteen papers were presented, eight of which were from men prominently associated with particular steel foundries and who were thus able to present first-hand practical experience of their own steelmelting furnaces. The other six papers were presented by men who fulfil the role of scientific advisers to the industry, and they included three members of the staff of the Association and three representing auxiliary industries.

The papers were not intended to be complete in themselves, but rather as introductions to the various phases of the subject, and were presented in such a manner as to encourage discussion, and so promote the dissemination of scientific information among those who are in a position to advance the standards of industrial achievement. The Association strongly supports the view that there is a great need for closer liaison between scientific workers and industry, and this is one of the reasons why such conferences as this are sponsored. In harmony with this idea, one of the most stimulating papers presented was by $\mathrm{Mr}$. F. A. Martin, chairman of the British Steel Founders' Association and leader of the first 'productivity team' to visit America, who made a challenging comparison of British and American productivity and the underlying causes for the differences. Naturally there was some criticism of American methods, but it was evident that all present accepted the rebuke that British industry had been slow to apply within itself scientific developments, which in many instances were made by British scientific men. The need for greater industrial enterprise and confidence in its own scientific workers was stressed, as also was the need on the part of men of science to expound their findings in a form of language more easily apprehensible to the community at large.

It was assumed that all existing furnaces of whatever type and throughout the world justify their use in the particular circumstances in which they are employed, or that there is no single type of furnace which has all the merit; and that whether the present distribution of the various types of furnace continues in the future depends upon scientific developments, which it was the object of the conference to study. For this reason the first two sessions commenced with a brief survey of the two principal types of melting 
process in use in Great Britain, namely, the cupola/ converter and the electric arc processes respectively ; while the third session dealt with other and less important processes, and the fourth session with the properties and cost of steel made by the various processes. Since a comparison of the processes was desired, discussion at each session was not limited to the particular papers presented at that session, and throughout there was lively discussion which probably constituted the major value of the conference. It is for this reason that the printed proceedings of the conference will include all the discussion-or at least as much of it as the contributors desire to be printed.

The first introductory paper on the cupola/converter process was prepared by Mr. F. Cousans, and it was followed by one on the design of converter by Mr. A. G. Robiette. The discussion on these two papers included a reference by Mr. M. P. Newby, of the Association's staff, to the work in hand in the laboratory with small-scale 'Perspex' models of converters in order to simulate furnace conditions and to provide a means of varying them experimentally. This drew one caustic comment typical of the response of mature experience to youthful and enthusiastic scientific experimentation, but none present questioned the potential value of such laboratory studies. The remark illustrated, however, how great is the gap between industrial knowledge or experience and that of the academic or scientific variety. Mr. A. J. Langner, of the staff of the Association, then explained the work in hand to desulphurize and de-phosphorize the metal more effectively, a matter for which there is great need and which thermodynamically is possible; and this was followed by an exposition by Dr. W. C. Newell of the principles and practice of oxygen enrichment applied to steel-making. This subject aroused much interest throughout the conference, and there is no doubt that it is one of those developments which could radically alter present-day steel-making practice. It also illustrates the value of co-operative research in pooling resources for the purpose of gaining scientific information from works' plant. Very often economic factors can deter industrial development, but these factors are notoriously changeable or at least capable of great change, and what was impracticable yesterday may become possible to-day and really attractive to-morrow. At the least, the scientific foundations are now laid for the application of oxygen enrichment to industrial steel-making, and already attractive economic, as well as technical, features are being demonstrated.

The second session opened with a paper by Mr. J. H. Pearce and Mr. W. Bramhall, in which the essential features about the operation of electric furnaces for foundries were explained; and this was followed by an account by Dr. J. R. Rait of the refractory lining of such furnaces. The discussion which followed revealed how much operating conditions influence refractory wear, and the practical steps which can be taken to reduce slag attack. It is probably not realized by those outside the steel industry how severe are the conditions of temperature and chemical activity in a steel-melting furnace, and this discussion showed how great is the problem of providing adequately resistant refractory lining to such a furnace. Mr. J. C. Howard then gave a paper on the electrical characteristics, output and design of electric arc furnaces, with the object of aiding a proper choice and technical control of these furnaces ; and Mr. J. Mowat followed with an account of openhearth furnace operation for foundry use. In a very frank way Mr. Mowat stated that he would not recommend the installation of such furnaces for foundries, but where they already exist for other steel requirements they are effective in also supplying foundry demands. Mr. F. A. Martin's paper on productivity, already referred to, then stirred up the conference to continue informal discussion upon the subject throughout the remaining evening. It is undoubtedly one of the advantages of holding such conferences in the agreeable surroundings of Ashorne Hill that informal discussion in the evenings is made so easy.

On the following morning, Mr. A. C. Brearley gave a lively and enthusiastic account of developments in German and American foundries during the past decade, reinforcing the emphasis already laid by $\mathrm{Mr}$. Martin on the American method of operation of acid electric are furnaces. Mr. C. McNair spoke about the operation of high-frequency furnaces, and $\mathrm{Mr}$. Howard explained the type of equipment involved and its manner of operation, a strong case being put forward for this type of furnace as a simple melting unit for relatively small quantities. In discussion, the authors were pressed about the possibility of refining steel in such furnaces, but little hope was raised for this prospect. It was admitted that the stirring action taking place in these furnaces might have the tendency to maintain inclusions in sus. pension, but that with due care in subsequent de. oxidation very clean steel is obtained, that is, sulphide and oxide inclusions are not excessive.

In the final session, Mr. J. E. Worthington, of the staff of the Association, gave a description of the work in hand upon the fluidity of steel, by which is meant the ability of steel to flow and completely and accurately follow the contour of a mould. A new laboratory technique has been developed, and with it the correlation of fluidity with temperature and a wide range of compositions has been explored. The effect of temperature and alloy content is now accurately known, and there remains the problem of studying the more subtle differences in fluidity associated with different types of furnace. The conference concluded with a paper by Mr. F. N. Lloyd on economic aspects of melting steel in foundries, a subject which had frequently been raised in discussion earlier in the conference.

The success of the conference may be judged by the attendance of 110 persons, about half of whom were from steel foundries, and from the keen discussion which they gave to the papers, both in the conference hall and informally on all other possible occasions. The scientific staff of the Association were inspired in their work by the personal contacts which they made with their industrial colleagues, who were in turn encouraged by the demonstration of the valuable research being performed on their behalf, so that the ultimate consequences may be far-reaching. The urge for greater technical efficiency and productivity was strongly implanted or strengthened, and American operation of acid electric furnaces was held up as a shining example, which it is to be hoped may assist steel founders in Britain. As was made clear, conditions in the United States differ from those in Britain in many ways, not the least being in the mental outlook of the peoples; but it is hoped that the conference did to some extent inspire all present to a fuller and more rapid application of available scientific knowledge. 